\author{
๑ Л. В. Багній, С. М. Геряк, Н. І. Багній \\ Тернопільський національний медичний університет ілені І. Я. Горбачевсъкого \\ МОЗ України

\section{ПАТОГЕНЕТИЧНІ АСПЕКТИ ФОРМУВАННЯ АКУШЕРСЬКИХ УСКЛАДНЕНЬ У ВАГІТНИХ ІЗ НЕАЛКОГОЛЬНОЮ ЖИРОВОЮ ХВОРОБОЮ ПЕЧІНКИ ПРИ НАДЛИШКОВІЙ МАСІ ТІЛА (ОГЛЯД ЛІТЕРАТУРИ)}

Серед патологічних станів, які є фракторами загрозливого перебігу вагітності, особливе місце посідають порушення ліпідного обміну, які на сьогодні прогресивно зростають. За даними ВООЗ, у 90 \% жінок із надлишковою масою тіла вже у віці 20-25 років виявляють ранні прояви стеатозу печінки, який впродовж наступних п'яти років життя приводить до неалкогольного стеатогепатиту. Тому жінки із надлишковою масою тіла мають загрозу щодо розвитку акушерських та перинатальних ускладнень, у генезі яких значна роль належить метаболічним порушенням у печінці.

Мета дослідження - проаналізувати дані сучасної літератури щодо показників ліпідного профілю, функції ендотелію, біохімічних маркерів, ролі печінки у регуляції ліпідного обміну та ключові фрактори ризику розвитку стеатозу в молодому віці, які можуть погіршити перебіг вагітності й пологів у вагітних із неалкогольною жировою хворобою печінки (НАЖХП) та ожирінням. Визначити оптимальні методи діагностики, профрілактики та лікування акушерських та перинатальних ускладнень у вагітних із надлишковою масою тіла при НАЖХП.

Висновок. Поєднання НАЖХП та ожиріння має вагомий вплив на розвиток акушерських та перинатальних ускладнень.

Ключові слова: неалкогольна жирова хвороба печінки; вагітність; порушення ліпідного обміну; фрункціональний стан печінки; акушерські ускладнення.

ПАТОГЕНЕТИЧЕСКИЕ АСПЕКТЫ ФОРМИРОВАНИЯ АКУШЕРСКИХ ОСЛОЖНЕНИЙ У БЕРЕМЕННЫХ С НЕАЛКОГОЛЬНОЙ ЖИРОВОЙ БОЛЕЗНЬЮ ПЕЧЕНИ ПРИ ИЗБЫТОЧНОЙ МАССЕ ТЕЛА (ОБЗОР ЛИТЕРАТУРЫ)

Среди патологических состояний, которые являются фракторами угрожающего течения беременности, особое место занимают нарушения липидного обмена. По данным ВО3, у $90 \%$ женщин с избыточной массой тела уже в возрасте 20-25 лет диагностируют ранние проявления стеатоза печени, который в течение следующих пяти лет жизни приводит к неалкогольному стеатогепатиту. Поэтому у женщин с избыточной массой тела имеется угроза развития акушерских и перинатальных осложнений, в генезисе которых значительная роль принадлежит метаболическим нарушениям в печени.

Цель исследования - проанализировать данные современной литературы относительно показателей липидного профриля, эндотелиальной фрункции, биохимических маркеров, роли печени в липидном обмене и ключевые фракторы риска развития стеатоза в молодом возрасте, которые могут ухудшить течение беременности и родов у беременных с неалкогольной жировой болезнью печени (НАЖБП). Определить оптимальные методы диагностики, профилактики и лечения акушерских и перинатальных осложнений у беременных с избыточной массой тела при НАЖБП.

Вывод. Сочетание НАЖБП и ожирения имеет значительное влияние на развитие акушерских и перинатальных осложнений.

Ключевые слова: неалкогольная жировая болезнь печени; беременность; нарушения липидного обмена; фрункциональное состояние печени; акушерские осложнения.

PATHOGENETIC ASPECTS OF THE OBSTETRIC COMPLICATIONS' FORMATION IN PREGNANT WOMEN WITH NONALCOHOLIC FATTY LIVER DISEASE IN OVERWEIGHT (LITERATURE REVIEW)

Among the pathological conditions that are factors threatening the course of pregnancy, a special place is occupied by disorders of lipid metabolism. According to the WHO, $90 \%$ of overweight women develop early manifestations of hepatic steatosis at the age of 20-25, which leads to non-alcoholic steatohepatitis over the next five years of life. Therefore, overweight women are at risk for the development of obstetric and perinatal complications, in the genesis of which a significant role is given to metabolic disorders in the liver.

The aim of the study - to analyze the current literature on lipid profile, endothelial function, biochemical markers, the role of the liver in the regulation of lipid metabolism and key risk factors for steatosis at a young age that may worsen pregnancy and childbirth in pregnant women with nonalcoholic fatty liver disease (NAFLD) and obesity and determine the optimal methods of diagnostics, prevention and treatment of obstetric and perinatal complications in overweight pregnant women with NAFLD.

Conclusion. The combination of NAFLD and obesity has a significant impact on the development of obstetric and perinatal complications.

Key words: nonalcoholic fatty liver disease; pregnancy; disorders of lipid metabolism; functional state of the liver; obstetric complications. 
Порушення ліпідного обміну є вагомим патологічним станом серед фракторів розвитку загрозливого перебігу вагітності, акушерських та перинатальних ускладнень. За даними ВОО3, у 90 \% жінок із надлишковою масою тіла вже у віці 20-25 років виявляють ранні прояви стеатозу печінки, який впродовж наступних п'яти років життя приводить до неалкогольного стеатогепатиту [1].

Водночас, захворювання, що входить у трійку найпоширеніших, - ожиріння у молодих жінок [2], - створює передумови для розвитку ранньої артеріальної гіпертензії, цукрового діабету, безпліддя та ін. Сучасні тенденції соціальної поведінки провокують недотримання основ раціонального харчування, за рахунок чого порушення ліпідного обміну в жінок репродуктивного віку стрімко зростає, при цьому його частота у вагітних становить від 9 до 20 \% [3]. Разом 3 тим, жінки із надлишковою масою тіла, порушеннями обміну речовин та метаболічними розладами у печінці мають загрозу щодо розвитку акушерських та перинатальних ускладнень [4].

Iз 2016 року, за рекомендацією European Association for the Study of the Liver (EASL), виділяють неалкогольну жирову хворобу печінки (НАЖХП) (К76.0) як «парасольковий» термін, який включає прогресуючі стани печінки, що різняться за ступенем тяжкості травми печінки та наслідком фріброзу [3]. Неалкогольний стеатогепатит (НАСГ) $\epsilon$ найбільш тяжкою фрормою НАЖХП та визначається накопиченням жиру в печінці, вміст якого перевищує $5 \%$ від її маси, супроводжується перицелюлярним фріброзом, який може прогресувати до цирозу та навіть гепатоцелюлярної карциноми [3, 4].

Сьогодні існує «вибухонебезпечний» інтерес до НАЖХП через зростаючий його вплив на здоров'я населення у світі. Так, у США, за прогнозами ВООЗ, кількість випадків НАСГ збільшиться до 100,9 млн у 2030 році проти 83,1 млн у 2015 році ( 25 \% від загальної кількості населення) $[5,6]$. Незважаючи на те, що неалкогольна жирова хвороба печінки зазвичай супроводжується центральним ожирінням, в Північній Америці та Європі ( 83 \% пацієнтів), в Азії є значний відсоток пацієнтів із «худорлявим НАСГ», які мають нормальний індекс маси тіла (IMT), навіть незважаючи на обмеження IMT для визначення надмірної маси тіла в Азії (IMT>23) (що $€$ нижчим, ніж у Північній Америці та Європі (IMT>25)) [5]. Поширеність НАСГ у країнах Європи також $€$ високою, де 25 \% загального населення має тенденцію до розвитку даного захворювання. Так, розповсюдженість по регіонах варіює від 8 \% у Румунії до 45 \% у Греції $[7,8]$. За результатами клініко-епідеміологічного дослідження DIREG 2, у Східній Європі серед 50145 амбулаторних пацієнтів частка осіб із встановленим діагнозом НАЖХП склала 37,3 \%. Поширеність НАЖХП (за винятком цирозу печінки) зростає в міру збільшення віку пацієнтів із 2,90\% (у 12-17 років) до 42,96 \% (у 60-69 років), тож у репродуктивному віці її частота коливається від 10 до 30 \% [9]

Окремі науковці виділяють НАЖХП як невід'ємний компонент метаболічного синдрому [10]. Причому збільшення поширеності та тяжкості перебігу НАЖХП у молодих жінок може бути пов'язане з тенденціями зростання ожиріння [11]. У ході окремих досліджень було виявлено, що у пацієнтів з абдомінальним ожирінням (AO), а також з іншими метаболічними порушеннями, у більшому відсотку випадків виявляють порушення фрункціонального стану печінки у вигляді НАЖХП [12]. Недавній аналіз Younossi Z. M. у 2016 році, в якому брали участь понад 8,5 мільйонів осіб із 22 країн, показав, що понад $80 \%$ пацієнтів із НАЖХП відмічали зайву масу або ожиріння, $72 \%$ мали дисліпідемію, 44 \% цукровий діабет 2 типу, а $54 \%$ - НАЖХП [13]. Тому можна вважати, що НАЖХП - це печінковий корелат метаболічного синдрому, системного розладу енергетичного гомеостазу та часто супроводжується вісцеральним ожирінням [13].

Втім, багато авторів вважають патогенез НАЖХП та НАСГ гіпотезою «двох ударів» $[1,14]$. На початковій стадії захворювання «перший удар» характеризується накопиченням жиру та тригліцеролів у печінці, інсулінорезистентністю, що відповідає стеатозу печінки, коли акумуляція жиру більш ніж 5 \% у печінці. Незабаром виникає «другий удар», що характеризується мітохондріальною дисфрункцією, оксидативним стресом, включенням прозапальних цитокінів та адипокінів, у результаті чого печінка $є$ більш чутливою. У такому випадку може виникати некрозапалення та фріброз, які приводять у кінцевому випадку до цирозу $[15,16]$. Однак у ході подальших досліджень ця гіпотеза є спрощеною для відображення комплексності НАЖХП та НАСГ.

На сьогодні основною теорією патогенезу НАЖХП вважається модель «множинних паралельних ударів», у якій визначну роль у пошкодженні печінки відіграють інсулінорезистентність [17], дисліпідемія [18], оксидативний стрес, ендотеліальна дисорункція та системне запалення [15].

Ожиріння [19] є значним фрактором ризику для матері, оскільки через вплив естрогену, прогестерону та плацентарного лактогену людини рівень ліпідів у плазмі крові значно збільшується [20], що пов' язано з гіпертригліцеридемією, спричиненою атенуйованою ендотелій-залежною релаксацією, при нормальному рівні ліпопротеїну низької щільності плазми (ЛПНЩ) рівень холестерину значно підвищується [21, 22]. М. J. Endresen дослідив два механізми порушення ліпідного просрілю під час вагітності. Перший - індукований естрогеном печінковий синтез тригліцеридів ліпопротеїдів дуже низької щільності (ЛПдНЩ) [23]. Другий механізм пояснює підвищення тригліцеридів у всіх циркулюючих ліпопротеїнах під час гестації порушенням видалення ліпопротеїну тригліцеридів одним або обома ліполітичними фрерментами, ліпопротеїновою ліпазою та печінковою ліпазою [23].

Нові дані підтверджують роль холестерину як важливого фрактора у патогенезі НАЖХП/НАСГ за рахунок прогресуючого підвищення вільного холестерину в печінці під час прогресування НАЖХП до НАСГ [24]. В експериментальних моделях показано, що підвищення рівня холестерину під час вагітності сприяє печінковому запаленню та фріброзу [25], тоді як дієта, що не містить холестерину, покращує перебіг НАСг під час вагітності [26]. Молекулярні механізми, що лежать в основі накопичення вільного холестерину у вагітних із НАСГ, множинні та лише частково з'ясовані. Поточні дані свідчать про те, що гомеостаз холестерину при НАЖХП у вагітних порушений через збільшення синтезу холестерину та поглинання або диссрункції метаболізму холестерину. Відповідно, активність двох ключових регуляторів синтезу холестерину - HMGCR та SREBP2 - підвищена у пацієнтів із НАСГ $[16,26]$. Аналогічно, експресійний аналіз 
генів, що беруть участь у метаболізмі холестерину, виявляє ряд патологічних ланок у вагітних із НАЖХП [26]. У печінці водночас відбувається поглинання «поганого» холестерину, що призводить до осадження кристалів холестерину в гепатоцитах та генерації пінистих клітин Купфрера - двох критичних особливостей НАЖХП [27]. Внутрішньоклітинне накопичення вільного холестерину під час вагітності $€$ ключовою подією для активації запалення та запальної реакції і сенсибілізації клітин до трансформації фрактора росту бета (TGF- $\beta$ ), TNF- $\alpha$ та Fas, що призводить, з одного боку, до ураження печінки та прогресування хвороби, а з другого боку - до розвитку патологічних ускладнень вагітності [26-28]. Крім того, холестерин ЛПнщ може бути окиснений до окисненого холестерину ліпопротеїдів низької щільності (oxLDL), який виявляється у високій концентрації в плазмі хворих на НАСГ [27], та індукує прозапальну цитокінову секрецію, що накопичується в лізосомах клітин Купфера, що при вагітності є ключовим у розвитку плацентарної диссрункції, невиношування, синдрому раптової смерті плода, синдрому затримки росту плода тощо [26, 28].

На сьогодні жирова тканина є високоактивною ендокринною залозою $[26,28,29]$, що синтезує ряд специфічних гормонів (лептин, резистин, адипонектин, вісфратин, апелін, ретинолзв' язуючий протеїн-4, тестостерон, естрон, ангіотензин), а також прозапальні цитокіни, такі як ІЛ-6, ІЛ-8, ФНП- $\alpha$ та регулятори ліпопротеїнового обміну (гормоночутлива ліпаза, ліпопротеїнова ліпаза, протеїн, що переносить ефіри холестеролу) [29, 30]. Під час вагітності, що супроводжується надмірною масою тіла та НАЖХП, синтез даних високоактивних сполук порушується та також відіграє важливу роль у розвитку як акушерських, так і перинатальних ускладнень [13].

Зазвичай вищий рівень лептину супроводжується ожирінням, однак лептин проявляє чутливість м'язової та жирової тканини до інсуліну, що в результаті попереджує надмірне скупчення адипоцитів. У більшості випадків у вагітних із надмірною масою тіла виявляють підвищений рівень лептину, що вказує на лептинорезистентність [31]. Лептинорезистентність порушує виведення вільних жирних кислот, спричиняє розвиток гіпертригліцеридемії та посилення процесу жирової інфільтрації печінки. Основні механізми дії лептину полягають у підвищенні печінкового глікогенолізу, транспорті продуктів обміну до скелетних м'язів, активації ліполізу і зменшенні вмісту тригліцеридів у жировій та інших тканинах без підвищення рівня вільних жирних кислот у плазмі. Отже, сама жирова тканина синтезує речовини, які знижують чутливість клітин до інсуліну (ТНФ- $\alpha$, лептин), руйнуючи зв'язок інсуліну зі специфрічними рецепторами в адипоцитах [30, 31]. Лептин виявляє антистеатогенну дію на ранніх стадіях захворювання, але він також може сприяти печінковому запаленню та фріброзу при прогресуванні НАЖХП [32]. У зв' язку з вагомим значенням лептину в регуляції ліпідного та енергетичного обмінів актуальним є дослідження його патогенетичних механізмів дії для створення дієвих засобів лікування НАЖХП на фоні ожиріння та профрілактики розвитку макросомії плода, плацентарної диссрункції та аномалій пологової діяльності.

Ще одним важливим адипокіном у патогенезі НАЖХП $€$ адипонектин, рівень якого при неалкогольному стеатогепатиті знижується [32]. Механізм дії даного адипо- кіну полягає в регуляції чутливості печінки до інсуліну, ß-окисленні ВЖК, гальмуванні накопичення ліпідів у жировій тканині та печінці [30-31]. Зниження рівня циркулюючого адипонектину служить сигналом інсулінорезистентності [32]. Ось чому багато робіт висвітлюють вагомість адипокіну в регуляції чутливості до інсуліну, гальмуванні глюконеогенезу. При цьому адипонектин вважають антиатерогенним, протидіабетичним, протизапальним та протиорібротичним медіатором, що впливає на стовбурові клітини крові та клітини Купфера [33]. Синтез адипонектину має негативну кореляцію з масою вісцеральної жирової тканини та запаленням в печінці. Зниження його концентрації в сироватці крові служить сигналом розвитку ожиріння [33-35]. Підвищена фуункція

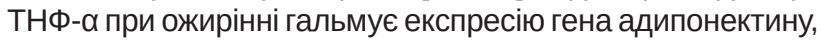
що пояснює його зниження на фоні надмірної маси тіла та метаболічного синдрому у вагітних $[34,36]$. Іншим потенційним фрактором, що пов'язує гіпертросрію адипоцитів із зменшеним синтезом адипонектину, $є$ мітохондріальна диссрункція [35]. Останні публікації показують, що експресія 11ß-гідроксистероїддегідрогенази типу 1 (11ß-HSD1) збільшується в гіпертрофрічних адипоцитах, і це може спричинити мітохондріальну дисфункцію та зменшення синтезу адипонектину, які відіграють вагому роль у патогенетичному механізмі розвитку пізнього гестозу у вагітних [36]. У своїх дослідженнях Matsuzawa [37] висвітлив позитивну роль адипонектину в зниженні тригліцеридів, підвищенні рівня ЛпВщ та нормалізації фрункції ендотелію.

Варто зауважити, що ендотеліальна дисфрункція $€$ одним із провідних патогенетичних механізмів розвитку як НАЖХП, так і ускладнень вагітності [38]. Ендотелій судин забезпечує судинний гомеостаз, відповідає за транспорт поживних речовин, регуляцію запальних і репаративних процесів та сигналізує про локальне пошкодження [39], а також синтезує ряд біологічно активних речовин: оксид азоту (NO), едотелін-1, тромбоксан, ангіотензин-1, інтерлейкін-1; регулює фрункцію згортання крові. Оксид азоту $є$ найбільш потужним вазодилататором, що синтезується із L-аргініну під впливом NO-синтаз. Десріцит L-аргініну або уповільнення синтезу NO-синтази приводять до недостатності оксиду азоту, який, у свою чергу, служить пусковим механізмом у розвитку ендотеліальної диссрункції та предиктором розвитку дистресу плода у вагітних, порушення кровотоку в артеріях пуповини тощо [38, 39].

Важливою патогенетичною ланкою у формуванні ендотеліальної диссрункції у вагітних із НАЖХП є збільшення рівня реактивних форм кисню (ROS), реактивних форм азоту (RNOS), асиметричного диметиларгініну (АДМА), зменшення синтезу монооксиду нітрогену (NO) при зниженні його біодоступності $[32,37]$. NO синтезується 3 L-аргініну під впливом трьох ізоформ NO-синтаз, $€$ вазодилататором та предиктором спазму судин різноманітного походження. NO має високі антиоксидантні властивості, однак при надмірній масі тіла та/або ожирінні збільшена концентрація вільних радикалів спричинює дезактивацію NO [39, 40], що приводить до зменшення еластичності судинної стінки, збільшення судинного опору та розвитку артеріальної гіпертензії, прееклампсії та кардіоваскулярних порушень у вагітних $[28,41]$. Дефріцит NO у вагітних приводить до порушення клубочкової фрільтрації та вазоспазму. На думку Caimi та Hoops (2012), 
десріцит L-аргініну є однією з причин зниження біодоступності NO, внаслідок чого фрормується ендотеліальна дисорункція під час вагітності [39].

Водночас Sheldon у 2015 році продемонстрував, що ендотеліальна дисоункція, яка супроводжується десріцитом NO, бере участь у прогресуванні НАЖХП та супроводжується активацією зірчастих клітин печінки, що приводить до розвитку НАСГ та артеріальної гіпертензії у вагітних [42].

Ang та Hillier (2001) встановили, що на початку вагітності синтез NO знижується, проте F. Medaglia et al. (2001) наголошують, що у другій половині вагітності вироблення NO ендотелієм судин зростає і таким чином адаптує серцево-судинну систему вагітної до збільшення об'єму циркулюючої крові [40].

A. Leiva et al. (2016) відмітили, що у плаценті при НАЖХП відбувається посилений синтез NO, однак, незважаючи на це, біодоступність NO знижується. Дані зміни можуть бути наслідком оксидативного стресу, що спостерігається при НАЖХП, оскільки NO вступає в реакцію з реактивними формами кисню, концентрація активних фоорм NO значно зменшується. Внаслідок даних змін існує очевидний ризик розвитку дистресу плода [41]

Підвищений рівень позаклітинного аденозину активує адренорецептори, що призводить до підвищеного синтезу NO, активації еNOS транспорту L-аргініну за рахунок активації катіонних амінокислот hCAT-1ds (Adenosine/Larginine/Nitric Oxide (ALANO) pathway). Дані порушення вказують на ендотеліальну дисорункцію $[41,42]$.

Асиметричний диметиларгінін (АДМА) регулює фрункцію ендотелію через інгібування eNOS, катіонних амінокислот, паралельно гальмуючи синтез NO. АДМА може сприяти розвитку ендотеліальної дисфункції та оксидативного стресу [20, 31]. Хоча Akturk та ін. (2010) повідомили, що рівень АДМА периферичної крові підвищений при НАЖХП, що вказує на активацію ендотелію та наслідки ендотеліальної дисорункції [43], a PoniedziałekCzajkowska та ін. (2016) вказують на те, що у вагітних із НАЖХП спостерігається значно нижчий рівень АДМА, ніж у здорових вагітних жінок, а також дане спостереження вказує на збільшений транспорт L-аргініну та синтез NO ендотелієм судин [44]. Важливо зазначити, що між цими двома дослідженнями існують деякі відмінності: в той час як Akturk et al. [43] вивчають нормальні та групи НАЖХП, подібні за статусом ожиріння, з індексом маси тіла

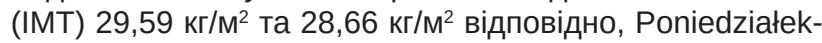
Czajkowska та ін. [44] порівнювали НАЖХП, що супро-

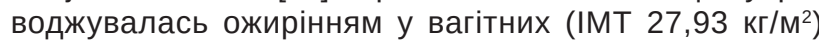
3 контрольною групою вагітних із нормальною масою тіла, $з$ ІМТ 22,34 кг/м².

Гіпоксія та ФНП- $а$ також відіграють важливу роль у пошкодженні функції ендотелію. На експериментальних моделях НАЖХП гіпоксія викликає зміни ліпідного гомеостазу, активуючи гени, що відповідають за ліпогенез SREBP-1c, PPARy, ACC1 або ACC2 та водночас гальмуючи гени, що беруть участь в метаболізмі ліпідів, таких як PPARa і карнітин пальмітоілтрансорераза-1 (CPT-1) [30, 33]. Окрім ліпідного обміну, також порушується інсулінова сигналізація, і в гіпоксичних умовах спостерігається печінкова регуляція запальних цитокінів та профріброгенних генів [13]. Крім того, зниження доступності кисню викликає секрецію адипокінів та запальних цитокінів у жировій тканині [29], сприяючи зміні ліпідного обміну та гомеостазу глюкози [32, 34, 39]. Ці ефекти опосередковуються чинниками транскрипції HIF-1 $\alpha$ та HIF-2a, які регулюють реакцію-відповідь клітин на дефріцит кисню, а також можуть активуватися іншими подразниками, включаючи окиснювальний стрес або запальні сигнали [44]. Разом 3 тим, встановлено, що гіпоксія модулює запалення, регулюючи експресію та срункцію TLR через HIF-1 [44, 23, 40]. Згідно $з$ цією схемою, активація неспецифрічної запальної реакції, яка спостерігається під час вагітності на тлі ожиріння та НАЖХП, може посилюватись гіпоксією завдяки механізму позитивного зворотного зв' язку із залученням HIF-1 $\alpha$ та NF-kB, що пояснює загострення ураження печінки у суб'єктів НАЖХП за наявності обструктивного синдрому апное - гіпопное (ОСАГС) та може бути причиною розвитку дистресу плода [43].

Оксидативний стрес виконує провідну роль у пошкодженні функції ендотелію [38] через можливість кисню утворювати активні сполуки з високою окисною здатністю, що формує ряд токсичних реакцій та неконтрольоване посилення процесів перекисного окиснення, яке приводить до різноманітних акушерських ускладнень; серед них важливе місце посідає дисфункція плаценти, дистрес плода, порушення пологової діяльності, гіпотонія матки, прееклампсія, кровотечі у II та III половині вагітності [32, 33, 38].

На основі доказів того, що велика кількість внутрішньоклітинних активних форм оксигену утворюється в мітохондріях та гіперпродукція активних форм кисню виявляється при порушенні дихальних ланцюгів, пошкодження мітохондрій було запропоновано як головну ланку в патогенезі НАСГ [33, 34, 39]. У вагітних із НАЖХП виявлено структурні та функціональні дефекти мітохондрій [39]. При цьому кілька механізмів, що сприяють порушенню мітохондрій та подальшій печінковоклітинній травмі під час НАСГ, в основному пов'язані з ліпотоксичністю. Встановлено, що після накопичення ліпідів приплив води та кальцію в мітохондріях збільшується за рахунок зниження фосфорилювання напруги залежного від напруги аніонного каналу (VDAC) у зовнішній мембрані мітохондрій, внаслідок чого спостерігається вивільнення цитохрому С та загибель клітин [41], що може відігравати важливу роль у розвитку дистресу плода та антенатальної його загибелі.

Оксидативний стрес відіграє провідну роль у виникненні та несприятливому перебігу НАЖХП під час вагітності [40]. Внаслідок інсулінорезистентності виникає вторинна гіперінсулінемія [23]. У свою чергу, інсулін стимулює вироблення супероксидного радикалу, активує НАДФН - оксидазу плазматичної мембрани фрібробластів, запальних клітин крові, а також адипоцитів [28], що сприяє порушенню метаболічних процесів у плаценті, зниженню ії трофрічної та ендокринної фуннццй.

Наявні численні наукові праці, у яких вказано як про підвищену чутливість абдомінального жиру до катехоламінів, які сприяють значному виділенню вільних жирних кислот, так і знижену його чутливість до антиліполітичної дії інсуліну $[8,29]$. Під впливом вторинної гіперінсулінемії та інсулінорезистентності рівень ЛПДНЩ зростає, а також стає резистентною ліпопротеїнліпаза, що бере участь в утворенні ЛПВЩ та виведенні ЛПдНЩ [20]. Таким чином забезпечується активний розпад лПВщ, що створює 
умови для синтезу атерогенних лпднщ і лпнщ та приводить до розвитку масивних петрисрікатів у плаценті, її гіпертрофії, макросомії плода, гіпотонії матки та виникнення слабкості пологової діяльності $[16,21]$.

Sankaralingam та ін. (2009) використовували плазму у жінок з прееклампсією для посилення виробництва НАДФН-оксидази супероксиду та пероксинітриту за допомогою активації lectin-like oxidized low-density lipoprotein receptor-1 в ендотеліальних клітинах [45]. Крім oxidatively modified low density lipoprotein, інші циркулюючі фрактори, які посилюються під час розвитку прееклампсії вагітних, також здатні активувати lectin-like oxidized low-density lipoprotein receptor-1. До них належать аніонні фроссроліпіди, апоптотичні клітини, активовані тромбоцити та бактерії [45]. Таким чином, шлях LOX-1 стає ключовим фрактором, що бере участь у фрормуванні ендотеліальної диссункції та серцево-судинних захворювань під час вагітності. Oxidatively modified low density lipoprotein збільшує індукцію гемоксигеназної системи-1 (НО-1) у відповідь на активні форми кисню $[41,43,45]$. Гемоксигеназна система-1 (HO-1) є потужним протизапальним та судинорозширювальним засобом, що чинить захисну дію проти широкого спектра патологічних станів під час вагітності [38, 39]. $€$ дослідження, у яких зазначалося, що НО-1 застосовувався при лікуванні серцево-судинних захворювань та артеріальної гіпертензії під час вагітності [42]. Крім того, дослідження, проведені на вагітних мишах, показали важливу участь гемоксигеназ у створенні та підтримці вагітності та адекватному плацентарному кровотоці [38]. Шлях НО-1 надає прямий ефект, інгібуючи вироблення ендотеліну-1 (ЕТ-1) у культивованих клітинах людського клубочкового ендотелію, що дозволяє припус-

\section{СПИСОК ЛІТЕРАТУРИ}

1. Mechanisms of NAFLD development and therapeutic strategies / S. L. Bredman, B. A. Neuschwander-Tetri, M. Rinella, A. J. Sanyal // Nat. Med. - 2018. - Vol. 24 (7). - P. 908-922.

2. Kedyk A. V. State of lipid and fat-acidic spectrum of blood plasma in the residents of the plain regions of transcarpathia depending on age and trophological status / A. V. Kedyk, I. V. Zhulkevych // Galician Medical Journal. - 2019. - Vol. 26 (1). - P. E201913.

3. EASL-EASD-EASO. Clinical Practice Guidelines for the management of non-alcoholic fatty liver disease // Diabetologia. - 2016. - Vol. 59 (6). - P. 1121-1140.

4. Epidemiology and natural history of non-alcoholic fatty liver disease / Y. Fazel, A. B. Koenig, M. Sayiner [et al.] // Metabolism. - 2016. - Vol. 65 (8). - P. 1017-1025.

5. Shumacher J. D. Mechanustic review of drug-induced steatohepatitits / J. D. Shumacher, G. L. Guo // Toxicol. Appl. Pharmacol. - 2015. - Vol. 289 (1). - P. 40-47.

6. Rinella M. E. Nonalcoholic fatty liver disease: a systematic review / M. E. Rinella // Jama. -2015. - Vol. 313 (22). - P. 2263-2273.

7. The burden of liver disease in Europe: a review of available epidemiological data / M. Blachier, H. Leleu, M. Peck-Radosavljevic [et al.] // J. Hepatol. - 2013. - Vol. 58 (3). - P. 593-608.

8. Nonalcoholic fatty liver and metabolic syndrome in Italy: results from a multicentric study of the Italian Arteriosclerosis society / M. Soresi, D. Noto, A. B. Cefalu [et al.] // Acta Diabetol. - 2013. - Vol. 50 (2). - P. 241-249.

9. Распространенность неалкогольной жировой болезни печени у пациентов амбулаторно-поликлинической прак- тити, що НО-1 може інгібувати продукцію ендотеліну-1, відіграючи важливу роль у регуляції артеріального тиску під час ішемії плаценти [42]. Про наявність ендотеліальної диссрункції у вагітних із надмірною масою тіла свідчать високі показники ЕT-1, що є передумовою розвитку змін оретоплацентарного комплексу і, як наслідок, виникнення синдрому затримки росту плода [37, 42, 45].

ВИсновкИ. 1. Незважаючи на значне поширення коморбідної патології у вагітних, звертає увагу недостатня кількість вагомих досліджень, у яких встановлено патогенетичні механізми фрункціональних порушень печінки у жінок із надлишковою масою тіла та особливості перебігу вагітності й пологів при НАЖХП. На сьогодні не розроблено також діагностично-прогностичних критеріїв своєчасного прогнозування, ранньої діагностики і лікування вагітних з ожирінням та НАЖХП із метою попередження акушерських та перинатальних ускладнень.

2. У проведеному нами огляді літератури проаналізовано зміни показників ліпідного профрілю та функції ендотелію, біохімічних маркерів, роль печінки у регуляції ліпідного обміну та ключові фрактори ризику розвитку стеатозу в молодому віці, які можуть погіршити перебіг вагітності та пологів у вагітних із НАЖХП та ожирінням.

3. Встановлено, що поєднання НАЖХП та ожиріння має вагомий вплив на розвиток акушерських та перинатальних ускладнень.

ПЕРСПЕКТИВИ ПОДАЛЬШИХ ДОСЛІДЖЕНЬ. У сучасній літературі недостатньо визначено роль НАЖХП на фроні порушення ліпідного обміну в патології перебігу вагітності, що вимагає подальших наукових досліджень у цьому напрямку та розробки програм прогнозування і своєчасного лікування акушерських ускладнень.

тики в Российской Федерации: результаты исследования DIREG 2 / В. Т. Ивашкин, О. М. Драпкина, И. В. Маев [и др.] // Российский журнал гастроэнтерологии, гепатологии, колопроктологии. - 2016. - Vol. 25 (6). - P. 31-41.

10. Степанов Ю. М. Результати обсерваційного перехресного дослідження PRELID 2 (2015-2016). Ч. 1. Поширеність неалкогольної жирової хвороби печінки, характеристика супутньої патології, метаболічного синдрому та його окремих критеріїв у пацієнтів, які звертаються до терапевтів і гастроентерологів в Україні / Ю. М. Степанов // Гастроентерологія. - 2019. - T. 53, № 1. - C. 26-33.

11. Weight gain during pregnancy. Committee Opinion No. 548 / American College of Obstetricians and Gynecologists // Obstet. Gynecol. - 2013. - Vol. 121. - P. 210-212.

12. Utility of noninvasive methods for the characterization of nonalcoholic liver steatosis in the family practice. The «VARES» Italian multicenter study / I. Grattagliano, E. Ubaldi, L. Napoli, [et al.] // Ann. Hepatol. - 2013. - Vol. 12 (1). - P. 70-77.

13. Global epidemiology of nonalcoholic fatty liver diseaseMeta-analytic assessment of prevalence, incidence, and outcomes / Z. M. Younossi, A. B. Koenig, D. Abdelatif [et al.] // Hepatology. - 2016. - Vol. 64 (1). - P. 73-84.

14. Бабак О. Я. Метаболічні зміни та малоінвазивна діагностика неалкогольного стеатогепатиту у хворих на неалкогольну жирову хворобу печінки на тлі гіпертонічної хвороби та ожиріння / О. Я. Бабак, К. А. Лапшина // Актуальні проблеми сучасної медицини: Вісник Української медичної стоматологічної академії. - 2016. - Т. 16, № 4, ч. 2. - С. 57-60. 
15. New obesity classification criteria as a tool for bariatric surgery indication / A. De Lorenzo, L. Soldati, F. Sarlo, M. Calvani // World J. Gastroenterol. - 2016. - Vol. 22 (2). - P. 681-703.

16. Berardis S. Pediatric non-alcoholic fatty liver disease: an increasingpublic issue / S. Berardis, E. Sokal // Eur. J. Pediatr. - 2014. - 173 (2). - Р. 131-139.

17. Аспекти корекції компенсаторної гіперінсулінемії та інсулінорезистентності у молодих жінок з ожирінням / Н. І. Корильчук, Т. Б. Корильчук, І. О. Боровик [та ін.] // Вісник наукових досліджень. - 2009. - № 4. - С. 66.

18. Indicators of lipid metabolism and their relation to disorders of microcirculation in diabetes mellitus / F. A. Zvershkhanovskil̆, I. V. Zhulkevich, V. S. Danilishina, G. D. Zhulkevich // Probl. Endokrinol. -1987. - Vol. 33 (4). -P. 15-18.

19. Корильчук Н. І. Ожиріння як передумова метаболічного синдрому (огляд літератури) / Н. І. Корильчук // Вісник наукових досліджень. - 2018. - № 2. - С. 24-28.

20. Blazina I. Diabetes drugs for nonalcoholic fatty liver disease: a systematic review / I. Blazina, S. Selph // Syst. Rev. - 2019. - Vol. 8 (1). - P. 295.

21. Simple noninvasive systems predict long-term outcomes of patients with nonalcoholic fatty liver disease / P. Angulo, E. Bugianesi, E. S. Bjornsson [et al.] // Gastroenterology. - 2013. - Vol. 145 (4). - P. 782-789.e4.

22. Zhulkevich, I.V., \& Vainshtein, S.G. (1986). Algorithm for phenotyping hyperlipoproteinemias and its application to the «Elektronika BZ-21» microcalculator. Laboratornoe delo, 10, 623-625.

23. Serum from preeclamptic women induces vascular cell adhesion molecule-1 expression on human endothelial cells in vitro: A possible role of increased circulating levels of free fatty acids / M. J. R. Endresen, J. M. Morris, A. C. Nobrega [et al.] // Am. J. Obstet. Gynecol. - 1998. - Vol. 179 (3). - P. 665-670.

24. The NAFLD fibrosis score: a noninvasive system that identifies liver fibrosis in patients with NAFLD / P. Angulo, J. M. Hui, G. Marchesini [et al.] // Hepatology. - 2007. - Vol. 45 (4). - P. 846-854.

25. Enhanced free cholesterol, SREBP-2 and star expression in human nash / F. Caballero, A. Fernandez, A. M. De Lacy [et al.] // J. Hepatol. - 2009. - Vol. 50 (4). - P. 789-796.

26. Synergistic interaction of dietary cholesterol and dietary fat in inducing experimental steatohepatitis / C. Savard, E. V. Tartaglione, R. Kuver [et al.] // Hepatology. - 2013. Vol. 57 (1). - P. 81-92.

27. Hepatic free cholesterol accumulates in obese, diabetic mice and causes nonalcoholic steatohepatitis / D. M. Van Rooyen, C. Z. Larter, W. G. Haigh [et al.] // Gastroenterology. 2011. - Vol. 141 (4). - P. 1393-1403.

28. Dietary cholesterol, rather than liver steatosis, leads to hepatic inflammation in hyperlipidemic mouse models of nonalcoholic steatohepatitis / K. Wouters, P. J. van Gorp V. Bieghs [et al.] // Hepatology. - 2008. - Vol. 48 (2). - P. 474-486.

29. Cholesterol synthesis is increased and absorption decreased in non-alcoholic fatty liver disease independent of obesity / P. Simonen, A. Kotronen, M. Hallikainen [et al.] // J. Hepatol. - 2011. - Vol. 54 (1). - P. 153-159.

30. Non-alcoholic steatohepatitis: The role of oxidized lowdensity lipoproteins / S. M. Walenbergh, G. H. Koek, V. Bieghs, R. Shiri-Sverdlov // J. Hepatol. - 2013. - Vol. 58 (4). - P. 801-810.
31. Free cholesterol accumulation in hepatic stellate cells: Mechanism of liver fibrosis aggravation in nonalcoholic steatohepatitis in mice / K. Tomita, T. Teratani, T. Suzuki [et al.] // Hepatology. - 2014. - Vol. 59 (1). - P. 154-169.

32. The diagnosis and management of non-alcoholic fatty liver disease: practice Guideline by the American Association for the Study of Liver Diseases, American College of Gastroenterology, and the American Gastroenterological Association / N. Chalasani, Z. Younossi, J. E. Lavine [et al.] // Hepatology. - 2012. - Vol. 55 (6). - P. 2005-2023.

33. Титов В. Н. Лептин и адипонектин в патогенезе метаболического синдрома / В. Н. Титов // Клиническая медицина. - 2014. - № 4. - С. 27-38.

34. How adiponectin, leptin, and ghrelin orchestrate together and correcale with severity of nonalcoholic fatty liver disease / M. Machado, J. Coutinho, F. Carepa [et al.] // Eur. J. Gastroenterol. Hepatol. - 2012. - Vol. 24 (10). - P. 1166-1172.

35. Relationships between inflammation, adiponectin, and oxidative stress in metabolic syndrome / S. J. Chen, C. H. Yen, Y. C. Huang [et al.] // PLoS One. - 2012. - Vol. 7 (9). - P. 45693.

36. Ghadge A. A. Adiponectin: a potential therapeutic target for metabolic syndrome / A. A. Ghadge, A. A. Khaire, A. A. Kuvalekar // Ctokine Gowth Facto Rev. - 2018. - Vol. 39. - P. 151-158.

37. Matsuzawa Y. Establishment of a concept of visceral fat syndrome and discovery ofadiponectin / Y. Matsuzawa // Proc. Jpn. Acad. Ser. B. Phys. Biol. Sci. - 2010. - Vol. 86 (2). P. 131-141.

38. The association of adiponectin and low-grade inflammation with the course of metabolic syndrome / T. M. Ahonen, J. T. Saltevo, H. J. Kautiainen [et al.] // Nutr. Metab. Cardiovasc. Dis. - 2012. - Vol. 22 (3). - P. 285-291.

39. Evaluation of nitric oxide metabolites in a group of subjects with metabolic syndrome / G. Caimi, E. Hoops, M. Montana, D. Noto // Diabetes Metab. Syndr. - 2012. Vol. 6 (3). - P. 132-135.

40. Insulin-mediated vasorelaxation in pregnancy / C. Ang C. Hillier, A. McDonald [et al.] // BJOG. - 2001. - Vol. 108 (10). - P. 1088-1093.

41. Nitric oxide is a central common metabolite in vascular dysfunction associated with diseases of human pregnancy / A. Leiva, B. Fuenzalida, E. Barros [et al.] // Curr. Vasc. Pharmacol. - 2016. - Vol. 14 (3). - P. 237-259.

42. Chronic NOS inhibition accelerates NAFLD progression in an obese rat model / R. D. Sheldon, J. Padilla, N. T. Jenkins, M. H. Laughlin // Am. J. Physiol. Gastrointest Liver Physiol. 2015. - Vol. 15 (308). - P. G540-549.

43. Asymmetric dimethylarginine concentrations are elevated in women with gestational diabetes / M. Akturk, A. Altinova, I. Mert [et al.] // Endocrine. - 2010. - Vol. 38 (1). - P. 134-141.

44. Intercellular adhesion molecule and endogenous NOS inhibitor: asymmetric dimethylarginine in pregnant women with gestational diabetes mellitus / E. Poniedzialek-Czajkowska, R. Mierzynski, D. Szymula [et al.] // J. Diabetes Res. - 2016. Vol. 2016. - P. 1342643.

45. Increased lectin-like oxidized low-density lipoprotein receptor-1 expression in the maternal vasculature of women with preeclampsia: role for peroxynitrite / S. Sankaralingam, Y. Xu, T. Sawamura, S. T. Davidge // Hypertension. - 2009. Vol. 53 (2). - P. 270-277. 


\section{REFERENCES}

1. Bredman, S.L., Neuschwander-Tetri, B.A., Rinella, M., \& Sanyal, A.J. (2018). Mechanisms of NAFLD development and therapeutic strategies. Nat. Med., 24 (7), 908-922. DOI: 10.1038/ s41591-018-0104-9.

2. Kedyk, A.V., \& Zhulkevych, I.V. (2019). State of lipid and fat-acidic spectrum of blood plasma in the residents of the plain regions of transcarpathia depending on age and trophological status. Galician Medical Journal, 26 (1), E201913.

3. EASL-EASD-EASO (2016). Clinical Practice Guidelines for the management of non-alcoholic fatty liver disease. Diabetologia, 59 (6), 1121-1140. DOI: 10.1007/s00125-016-3902-y.

4. Fazel, Y., Koenig, A.B., Sayiner, M., Goodman, Z.D., \& Younossi, Z.M. (2016). Epidemiology and natural history of non-alcoholic fatty liver disease. Metabolism, 65 (8), 1017-1025. DOI: 10.1016/j.metabol.2016.01.012.

5. Shumacher, J.D., \& Guo, G.L. (2015). Mechanustic review of drug-induced steatohepatitits Mechanustic review of druginduced steatohepatitits. Toxicol. Appl. Pharmacol., 289 (1), 40-47. DOI: 10.1016/j.taap.2015.08.022.

6. Rinella, M.E. (2015). Nonalcoholic fatty liver disease: a systematic review. Jama, 313 (22), 2263-2273. DOI: 10.1001/ jama.2015.5370.

7. Blachier, M., Leleu, H., Peck-Radosavljevic, M., Valla, D.C., \& Roudot-Thoraval, F. (2013). The burden of liver disease in Europe: a review of available epidemiological data. J. Hepatol., 58 (3), 593-608. DOI: 10.1016/j.jhep.2012.12.005.

8. Soresi, M., Noto, D., Cefalu, A.B., Martini, S., Vigna, G.B., Fonda, M., ..., \& Notarbartolo, A. (2013). Nonalcoholic fatty liver and metabolic syndrome in Italy: results from a multicentric study of the Italian Arteriosclerosis society. Acta Diabetol., 50 (2), 241-249. DOI: 10.1007/s00592-012-0406-1.

9. Ivashkin, V.T., Drapkina, O.M., Mayev, I.V., Trukhmanov, A.S., Blinov, D.V., Palgova, L.K., ..., \& Ushakova, T.I. (2016). Rasprostranennost nealkogolnoy zhirovoy bolezni pecheni u patsiyentov ambulatorno- poliklinicheskoy praktiki v Rossiyskoy Federatsii: rezultaty issledovaniya DIREG 2 [Prevalence of non-alcoholic fatty liver disease in outpatients in the Russian Federation: results from the DIREG 2 study]. Rossiyskiy zhurnal gastroenterelogii, gepatologii, koloproktologii - Russian Journal of Gastroenterology, Hepatology, Coloproctology, 25 (6), 31-41 [in Russian].

10. Stepanov, Yu.M. (2019). Rezultaty observatsiinoho perekhresnoho doslidzhennia PRELID 2 (2015-2016). Ch. 1. Poshyrenist nealkoholnoi zhyrovoi khvoroby pechinky, kharakterystyka suputnoi patolohii, metabolichnoho syndromu ta yoho okremykh kryteriiv u patsiientiv, yaki zvertaiutsia do terapevtiv i hastroenterolohiv $v$ Ukraini [Results of the observational crosssectional study PRELID 2 (2015-2016). Part 1. Prevalence of non-alcoholic fatty liver disease, characteristics of concomitant pathology, metabolic syndrome and its individual criteria in patients who turn to therapists and gastroenterologists in Ukraine]. Hastroenterolohiia - Gastroenterology, 53 (1), 26-33 [in Ukrainian].

11. American College of Obstetricians and Gynecologists (2013). Weight gain during pregnancy. Committee Opinion No. 548. Obstet. Gynecol., 121, 210-212. DOI: 10.1097/01. aog.0000425668.87506.4c.

12. Grattagliano, I., Ubaldi, E., Napoli, L., Marulli, C.F., Nebiacolombo, C., Cottone, C., \& Portincasa, P. (2013). Utility of noninvasive methods for the characterization of nonalcoholic liver steatosis in the family practice. The "VARES" Italian multicenter study. Ann. Hepatol., 12 (1), 70-77.

13. Younossi, Z.M., Koenig, A.B., Abdelatif, D., Fazel, Y., Henry, L., \& Wymer, M. (2016). Global epidemiology of nonal- coholic fatty liver disease-Meta-analytic assessment of prevalence, incidence, and outcomes. Hepatology, 64 (1), 73-84. DOI: 10.1002/hep.28431.

14. Babak, O.Ya., \& Lapshyna, K.A. (2016). Metabolichni zminy ta maloinvazyvna diahnostyka nealkoholnoho steatohepatytu u khvorykh na nealkoholnu zhyrovu khvorobu pechinky na tli hipertonichnoi khvoroby ta ozhyrinnia [Metabolic changes and minimally invasive diagnosis of non-alcoholic steatohepatitis in patients with non-alcoholic fatty liver disease on the background of hypertension and obesity]. Aktualni problemy suchasnoi medytsyny: Visnyk Ukrainskoi medychnoi stomatolohichnoi akademii - Actual problems of modern medicine: Bulletin of the Ukrainian Medical Dental Academy, 16 (4, ch. 2), 57-60 [in Ukrainian].

15. De Lorenzo, A., Soldati, L., Sarlo, F., \& Calvani, M. (2016). New obesity classification criteria as a tool for bariatric surgery indication. World J. Gastroenterol., 22 (2), 681-703. DOI: 10.3748/wjg.v22.i2.681.

16. Berardis, S., \& Sokal, E. (2014). Pediatric non-alcoholic fatty liver disease: an increasingpublic issue. Eur. J. Pediatr., 173 (2), 131-139. DOI: 10.1007/s00431-013-2157-2156.

17. Korylchuk, N.I., Korylchuk, T.B., Borovyk, I.O., Botsiuk, N.Ye., Riabokon, S.S., Tvorko, V.M., \& Mihenko, B.O. (2009). Aspekty korektsiii kompensatornoi hiperinsulinemii ta insulinorezystentnosti u molodykh zhinok z ozhyrinniam [Aspects of correction of compensatory hyperinsulinemia and insulin resistance in young obese women]. Visnyk naukovykh doslidzhen - Bulletin of Scientific Research, 4, 66 [in Ukrainian].

18. ZvershkhanovskiĬ, F.A., Zhulkevich, I.V., Danilishina, V.S., \& Zhulkevich, G.D. (1987). Indicators of lipid metabolism and their relation to disorders of microcirculation in diabetes mellitus. Probl. Endokrinol., 33 (4), 15-18.

19. Korylchuk, N.I. (2018). Ozhyrinnia yak peredumova metabolichnoho syndromu (ohliad literatury) [Obesity as a precondition for metabolic syndrome (literature review)]. Visnyk naukovykh doslidzhen - Bulletin of Scientific Research, 2, 24-28. DOI: 10.11603/2415-8798.2018.2.9192 [in Ukrainian].

20. Blazina, I., \& Selph, S. (2019). Diabetes drugs for nonalcoholic fatty liver disease: a systematic review. Syst. Rev., 8 (1), 295. DOI: 10.1186/s13643-019-1200-8.

21. Angulo, P., Bugianesi, E., Bjornsson, E.S., Charatcharoenwitthaya, P., Mills, P.R., Barrera, F., ..., \& George, J. (2013). Simple noninvasive systems predict long-term outcomes of patients with nonalcoholic fatty liver disease. Gastroenterology, 145 (4), 782-789.e4. DOI: 10.1053/j.gastro.2013.06.057.

22. Zhulkevich, I.V., \& Vainshtein, S.G. (1986). Algorithm for phenotyping hyperlipoproteinemias and its application to the "Elektronika BZ-21" microcalculator. Laboratornoe delo, 10, 623-625.

23. Endresen, M.J.R., Morris, J.M., Nobrega, A.C., Buckley, D., Linton, E.A., \& Redman, C.W.G. (1998). Serum from preeclamptic women induces vascular cell adhesion molecule-1 expression on human endothelial cells in vitro: A possible role of increased circulating levels of free fatty acids. Am. J. Obstet. Gynecol., 179 (3), 665-670. DOI: 10.1016/s0002-9378(98)70061-4.

24. Angulo, P., Hui, J.M., Marchesini, G., Bugianesi, E., George, J., Farrell, G.C., ..., \& Day, C.P. (2007). The NAFLD fibrosis score: a noninvasive system that identifies liver fibrosis in patients with NAFLD. Hepatology, 45 (4), 846-854. DOI: 10.1002/hep.21496.

25. Caballero, F., Fernandez, A., De Lacy, A.M., FernandezCheca, J.C., Caballeria, J., \& Garcia-Ruiz, C. (2009). Enhanced free cholesterol, SREBP-2 and star expression in human nash. J. Hepatol., 50 (4), 789-796. DOI: 10.1016/j.jhep.2008.12.016. 
26. Savard, C., Tartaglione, E.V., Kuver, R., Haigh, W.G., Farrell, G.C., Subramanian, S., ..., \& Ioannou, G.N. (2013). Synergistic interaction of dietary cholesterol and dietary fat in inducing experimental steatohepatitis. Hepatology, 57 (1), 81-92. DOI: 10.1002/hep.25789.

27. Van Rooyen, D.M., Larter, C.Z., Haigh, W.G., Yeh, M.M., Ioannou, G., ..., \& Farrell, G.C. (2011). Hepatic free cholesterol accumulates in obese, diabetic mice and causes nonalcoholic steatohepatitis. Gastroenterology, 141 (4), 1393-1403. DOI: 10.1053/j.gastro.2011.06.040.

28. Wouters, K., van Gorp, P.J., Bieghs, V., Gijbels, M.J., Duimel, H., Lutjohann, D., ..., \& Hofker, M.H. (2008). Dietary cholesterol, rather than liver steatosis, leads to hepatic inflammation in hyperlipidemic mouse models of nonalcoholic steatohepatitis. Hepatology, 48 (2), 474-486. DOI: 10.1002/hep.22363.

29. Simonen, P., Kotronen, A., Hallikainen, M., Sevastianova, K., Makkonen, J., Hakkarainen, A., ..., \& Yki-Jarvinen, H. (2011). Cholesterol synthesis is increased and absorption decreased in non-alcoholic fatty liver disease independent of obesity. $J$. Hepatol., 54 (1), 153-159. DOI: 10.1016/j.jhep.2010.05.037.

30. Walenbergh, S.M., Koek, G.H., Bieghs, V., \& ShiriSverdlov, R. (2013). Non-alcoholic steatohepatitis: The role of oxidized low-density lipoproteins. J. Hepatol., 58 (4), 801-810. DOI: 10.1016/j.jhep.2012.11.014.

31. Tomita, K., Teratani, T., Suzuki, T., Shimizu, M., Sato, H., Narimatsu, K., ..., \& Hibi, T. (2014). Free cholesterol accumulation in hepatic stellate cells: Mechanism of liver fibrosis aggravation in nonalcoholic steatohepatitis in mice. Hepatology, 59 (1), 154-169. DOI: 10.1002/hep.26604.

32. Chalasani, N., Younossi, Z., Lavine, J.E., Diehl, A.M., Brunt, E.M., Cusi, K., ..., \& Sanyal, A.J. (2012). The diagnosis and management of non-alcoholic fatty liver disease: practice Guideline by the American Association for the Study of Liver Diseases, American College of Gastroenterology, and the American Gastroenterological Association. Hepatology, 55 (6), 2005-2023. DOI: 10.1002/hep.25762.

33. Titov, V.N. (2014). Leptin i adiponektin v patogeneze metabolicheskogo sindroma [Leptin and adiponectin in the pathogenesis of metabolic syndrome]. Klinicheskaya meditsina - Clinical Medicine, 4, 27-38 [in Russian].

34. Machado, M., Coutinho, J., Carepa, F., Costa, A., Proenca, H., \& Cortez-Pinto, H. (2012). How adiponectin, leptin, and ghrelin orchestrate together and correcale with severity of nonalcoholic fatty liver disease. Eur. J. Gastroenterol. Hepatol., 24 (10), 1166-1172. DOI: 10.1097/MEG.0b013e32835609b0.

35. Chen, S.J., Yen, C.H., Huang, Y.C., Lee, B.J., Hsia, S., \& Lin, P.T. (2012). Relationships between inflammation, adipo- nectin, and oxidative stress in metabolic syndrome. PLoS One, 7 (9), 45693. DOI: 10.1371/journal.pone.0045693.

36. Ghadge, A.A., Khaire, A.A., \& Kuvalekar, A.A. (2018). Adiponectin: a potential therapeutic target for metabolic syndrome. Ctokine Gowth Facto Rev., 39, 151-158. DOI: 10.1016/j. cytogfr.2018.01.004.

37. Matsuzawa, Y. (2010). Establishment of a concept of visceral fat syndrome and discovery ofadiponectin. Proc. Jpn. Acad. Ser. B. Phys. Biol. Sci., 86 (2), 131-141. DOI: 10.2183/ pjab.86.131.

38. Ahonen, T.M., Saltevo, J.T., Kautiainen, H.J., Kumpusalo, E.A., \& Vanhala, M.J. (2012). The association of adiponectin and low-grade inflammation with the course of metabolic syndrome. Nutr. Metab. Cardiovasc. Dis., 22 (3), 285-291. DOI: 10.1016/j.numecd.2010.07.001.

39. Caimi, G., Hoops, E., Montana, M., \& Noto, D. (2012). Evaluation of nitric oxide metabolites in a group of subjects with metabolic syndrome. Diabetes Metab. Syndr., 6 (3), 132-135. DOI: 10.1016/j.dsx.2012.09.012.

40. Ang, C., Hillier, C., MacDonald, A., Cameron, A., Greer, I., \& Lumsden, M.A. (2001). Insulin-mediated vasorelaxation in pregnancy. BJOG, 108 (10), 1088-1093. DOI: 10.1111/j.14710528.2001.00257.x.

41. Leiva, A., Fuenzalida, B., Barros, E., Sobrevia, B., Salsoso, R., Sáez, T., ..., \& Sobrevia, L. (2016). Nitric oxide is a central common metabolite in vascular dysfunction associated with diseases of human pregnancy. Curr. Vasc. Pharmacol., 14 (3), 237-259. DOI: 10.2174/1570161114666160222115158.

42. Sheldon, R.D., Padilla, J., Jenkins, N.T., \& Laughlin, M.H. (2015). Chronic NOS inhibition accelerates NAFLD progression in an obese rat model. Am. J. Physiol. Gastrointest Liver Physiol., 15 (308), G540-549. DOI: 10.1152/ajpgi.00247.2014.

43. Akturk M., Altinova A., Mert I., Dincel A., Sargin A., Buyukkagnici U., ..., \& Danisman, N. (2010). Asymmetric dimethylarginine concentrations are elevated in women with gestational diabetes. Endocrine, 38 (1), 134-141. DOI: 10.1007/ s12020-010-9361-1.

44. Poniedzialek-Czajkowska, E., Mierzynski, R., Szymula, D., Leszczynska-Gorzelak, B., \& Oleszczuk, J. (2016). Intercellular adhesion molecule and endogenous NOS inhibitor: asymmetric dimethylarginine in pregnant women with gestational diabetes mellitus. J. Diabetes Res., 2016, 1342643. DOI: 10.1155/2016/1342643.

45. Sankaralingam, S., Xu, Y., Sawamura, T., \& Davidge, S.T. (2009). Increased lectin-like oxidized low-density lipoprotein receptor-1 expression in the maternal vasculature of women with preeclampsia: role for peroxynitrite. Hypertension, 53 (2), 270-277. DOI: 10.1161/HYPERTENSIONAHA.108.122630.

Отримано 16.09.20

Прийнято до друку 20.10.20

Електронна адреса для листування: bahnii@tdmu.edu.ua 